\title{
From the European Stability Mechanism to the European Monetary Fund: There and Back Again
}

\author{
Mauro Megliani*
}

(Accepted 19 August 2019)

\begin{abstract}
In December 2018, the Euro Summit endorsed the Term Sheet on the European Stability Mechanism (ESM) reform prepared by the Eurogroup. In this context, the Euro Summit did not acknowledge the proposal of the European Commission to transform the ESM into the European Monetary Fund (EMF), but simply gave the Eurogroup a mandate to draft the relevant amendments to the ESM Treaty and submit them to the European Council of June 2019. Nonetheless, the justifications for the incorporation of the ESM into the body of the European Treaties continue to be valid and may come back into play. In this respect, it is worth highlighting two flaws that have emerged in the proposed transformation of the ESM into the EMF. First, the ESM Treaty does not contain any rule about extinction and transfer of functions. Second, the Commission's proposal did not clarify what status the EMF would have enjoyed in the EU legal framework.
\end{abstract}

Keywords: European Stability Mechanism; European Monetary Fund; failed transformation; international organizations; succession by absoprtion

\section{A. Introduction}

On December 14, 2018, the Euro Summit endorsed the Term Sheet on the European Stability Mechanism (ESM) reform formalized by the Eurogroup on December 4, 2018. ${ }^{1}$ The Term Sheet is based on four key points: (1) The ESM will provide financial assistance to the Single Resolution Fund (SRF) in the form of a revolving credit line; (2) recourse to the Precautionary Conditioned Credit Lines is possible if certain quantitative criteria are met; (3) ESM financial assistance is to be granted only to those countries whose debt is sustainable and the capacity for repayment indisputable; and (4) the ESM and the European Commission will cooperate within, and outside, the financial assistance programs. The Eurogroup was mandated to incorporate these points in amendments to the ESM Treaty to be submitted to the European Council of June 2019. In June 2019, though, the Euro Summit did not approve the revised draft ESM Treaty but invited the Eurogroup to continue working so as to reach an agreement by the European Council of December 2019. ${ }^{2}$ In December 2019 the Euro Summit

\footnotetext{
${ }^{\star}$ Mauro Megliani is a tenured assistant professor of International Law at the Catholic University of Milan, mauro. megliani@unicatt.it.

${ }^{1}$ See generally Term Sheet on the European Stability Mechanism Reform (2018), https://www.consilium.europa.eu/ media/37267/esm-term-sheet-041218_final_clean.pdf.

${ }^{2}$ See generally European Council Press Release EURO 502/19, Statement of the Euro Summit (June 21, 2019).
} 
was unable to approve the final text because of a disagreement on the introduction of the single-limb action clauses aimed at facilitating a debt restructuring process. ${ }^{3}$

In this picture, the missing point is any reference to the projected transformation of the ESM into a proper European Monetary Fund. In fact, in December 2017, the European Commission had presented a proposal for an EU Council Regulation for the transformation of the ESM into the EMF and its incorporation in the framework of the European Treaties. ${ }^{4}$ This transformation was meant to complete the European Monetary Union by providing unity, efficiency, and democratic accountability. From a formal point of view, the Commission proposal involved the extinction of the ESM as an international organization in its own right and the establishment of the EMF as a new institution within the European Treaties.

Although any reference to the transformation of the ESM into the EMF was dropped out, the reasons for the incorporation of the ESM into the body of the European Treaties continue to be valid and may come back into play. Against this background, the purpose of this Article is to illustrate the mechanisms of financial assistance to European countries, to delineate the proposal of the Commission, and to highlight the transformation of the ESM into the EMF, with specific reference to the forms and the methods and the results of this transformation. In this context, particular attention will be given to the modalities of transformation in the absence of a specific provision in the ESM Treaty and to the status the EMF would have enjoyed in the EU legal system. In some way, this Article is meant to be as a benchmark for when times are ripe for a resumption of the EMF proposal.

\section{B. Financial Assistance to Euro Countries: From the No Bail-Out Rule to the ESM}

Following the coming into force of the monetary union, the Euro countries were no longer entitled to receive financial assistance under the scheme of the balance of payments facility (Article 143 TFEU). ${ }^{5}$ This lacuna derived from the deliberate choice of the drafters of the Maastricht Treaty to leave to the financial markets the task of imposing the fiscal discipline on borrowing states. ${ }^{6}$ In the long term, the assumption on which this choice was based turned out to be wrong.

In May 2010, Greece was on the verge of a financial crisis because it was not able to refinance its public debt by issuing new bonds on the markets. As a default on the Greek debt would have endangered the single currency, the Euro countries arranged a mechanism for financial assistance to Greece in the form of a pool of bilateral loans. ${ }^{7}$ This ad hoc facility was followed in June 2010 by the establishment of a semi-permanent mechanism, the European Financial Stability Facility (EFSF), that was constituted in the form of a corporation (société anonyme) registered in Luxembourg and subject to the laws of Luxembourg. ${ }^{8}$ This mechanism was aimed at preserving the financial stability of the monetary union by providing temporary assistance to Euro countries

\footnotetext{
${ }^{3}$ See generally Mauro Megliani, The European Stability Mechanism Reform and the Single-Limb Collective Action Clauses, 32 EUR. Bus. L. REV. (forthcoming 2021).

${ }^{4}$ See Proposal for a Council Regulation on the Establishment of the European Monetary Fund, COM (2017) 827 final (Dec. 6, 2017) [hereinafter Regulation proposal]. The Statute of the EMF is an Annex to the Regulation proposal [hereinafter EMF Statute].

${ }^{5}$ See Dominique Carreau, Art 108, in Traité instituant la CEE: Commentaire article par article 617 (Vlad Constantinesco et al. eds., 1992); cf. Council Regulation 332/2002 of Feb. 18, 2002, Establishing a Facility Providing Medium-Term Financial Assistance for Member States' Balance Payments, 2002 O.J. (L 53) 1 (EC).

${ }^{6}$ See Jean-Victor Louis, The No-Bailout Clause and Rescue Packages, 47 Common MKT. L. REV. 971, 979-82 (2010).

${ }^{7}$ See Euro Area Loan Facility Act 2010, No. 7 of 2010 (May 20, 2010), https://data.oireachtas.ie/ie/oireachtas/act/2010/7/ eng/enacted/a710.pdf. In a first document-the Intercreditor Agreement- the Euro countries committed themselves to providing eighty billion Euros to Greece. In a second document— the Loan Facility Agreement - the Euro countries formalized the terms of the loan with Greece, the provision of which was conditional upon the compliance of a specific memorandum of economic policy.

${ }^{8}$ The Company was agreed on by the-then-sixteen Euro countries on May 9, 2010, and incorporated under Luxembourgish law on June 7, 2010; the Statute is on file with the author.
} 
experiencing financial difficulties on the basis of a memorandum of economic policy. ${ }^{9}$ The EFSF was not meant to be permanent: Its establishing instrument stipulated that no loan facility agreement would be granted after June 30, 2013 (Article 4).

To fill this lacuna, the European Council of March 24-25, 2011, resolved to add a new paragraph to Article 136 TFEU, under which the Member States whose currency was the Euro were allowed to establish a stability mechanism to be activated to safeguard the financial stability of the Euro area as a whole. ${ }^{10}$ The stability mechanism was formalized in a treaty establishing the ESM. ${ }^{11}$ The first version was signed in Brussels on July 11, 2011, with the second and definitive version signed in Brussels on February 1, 2012.12 The purpose of the ESM is to mobilize funding and provide stability support, under strict policy conditionality, in favor of the ESM Members States who are experiencing, or are threatened by, severe financing problems, as far as this intervention is indispensable for the preservation of the financial stability of the whole Euro area and of its Member States (Article 3).

The ESM is structured as follows: A Board of Governors, composed of a Governor for each Member State in the person of the member of the national government responsible for finance (Article 5(1)); a Board of Directors, composed of a person appointed by each Governor among persons of high competence in economic and financial matters, who are revocable an time (Article 6(1)); and, finally, a Managing Director, appointed by the Board of Governors (Article 7(1)). The President of the Euro Group may attend the meetings of the Board of Governors as an observer, together with the President of the ECB and the Commissioner for Economic and Monetary Affairs (Article 5(3)). Representatives of non-Euro countries taking part in financial assistance operations in favor of an ESM member may be invited to attend the relevant meetings as observers; in addition, representatives of the IMF or other organizations and institutions may occasionally be invited to attend meetings as observers (Articles 5(4), 5(5)).

From an institutional standpoint, the ESM amounts to a new international organization designed to operate alongside the EU. The failure to incorporate such a body within the framework of the European Treaties reflects the tendency by the Euro countries to Flucht in Völkerrecht (flight to international law) as a substitute for EU action. ${ }^{13}$ In effect, EU law does not prevent Member States from concluding agreements between themselves, ${ }^{14}$ even though this involves a form of differential integration. ${ }^{15}$ The legality of the establishment of the ESM was challenged

\footnotetext{
${ }^{9}$ See Mauro Megliani, Verso una Nuova Architettura Finanziaria Europea: Un Percorso Accidentato, 27 Dir. Comm. INT. 66, 81-84 (2013).

${ }^{10}$ See European Council Decision 2011/199/EU of 25 Mar. 2011 Amending Article 136 of the Treaty on the Functioning of the European Union with Regard to a Stability Mechanism for Member States Whose Currency is the Euro, 2011 O.J. (L 91) 1. The amendment to the TFEU was made through the simplified procedure envisaged in Article 48(6) TEU, namely, without the call for a convention, but with the respect of the constitutional rules of the Member States, whose unanimity is expressed within the European Council. The route taken was not to create the mechanism within the framework of the Treaties under Article 352 TFEU, as according to the Lisbon Judgment (decision of the Bundesverfassungsgericht [BVerfG] [Federal Constitutional Court] June 30, 2009, 2 EnTSCHEIdUNGEN DES BundeSVERfassungsGerichts [BVERFGE] 2/08, para. 328, http://www.bverfg.de/entscheidungen/es20090630_2bve000208en.html) as a step like that would have required the previous assent of the German Parliament.

${ }^{11}$ See Matthias Ruffert, The European Debt Crisis and European Union Law, 48 Common MKT. L. Rev. 1777, 1783 (2011) (stating that the ESM can be seen both as a public international law Special Purpose Vehicle and as a European version of the International Monetary Fund).

${ }^{12}$ See European Commission Press Release D/12/3, Treaty Establishing the European Stability Mechanism (ESM) (Feb. 1, 2012) [hereinafter ESM Treaty]. The new version of the ESM Treaty has incorporated the modifications introduced as a result of the decisions made at the European Councils of July 21, 2011, such as, precautionary program, recapitalization of financial institutions, intervention in the secondary markets, and as of December 9, 2011, involvement of the private sector in line with the IMF principles and practices, and emergency procedure.

${ }^{13}$ See Ulrich Häde, Euro-Rettung ZWISChEn EXeKutivprimat und Parlamentsvorberhalt 15-16 (2012).

${ }^{14}$ See Damian Chalmers et al., European Union Law: TeXt and Materials 141 (3d ed. 2014).

${ }^{15}$ See Chalmers ET AL., supra note 14, at 142.
} 
before the ECJ in the Pringle case. ${ }^{16}$ In this context, the ECJ was asked, inter alia, to clarify whether or not the establishment of the ESM had affected the competence of the EU to establish such a mechanism. The ECJ dismissed the argument, ruling that the provisions of the TFEU in the domain of economic policy do not confer any specific power upon the EU institutions to establish such a mechanism (paragraph 64). ${ }^{17}$ Further, under Article 352 TFEU-the so-called flexibility clause - the EU institutions are not obliged to act, but are simply enabled to do so (paragraph. 67). ${ }^{18}$ Thereby, Member States were entitled to conclude the ESM agreement (paragraph 68), even though in doing so they were called upon to comply with $\mathrm{EU} \mathrm{law}^{19}$ and to subject the provision of resources to conditionality (paragraph 69 ). ${ }^{20}$

\section{From the ESM to the EMF}

In December 2017, the European Commission submitted a proposal to the EU Council to transform the ESM into the EMF and to incorporate it into the EU legal framework. The Commission justified this step with reference to the necessity to further strengthen the ESM institutional anchoring-particularly in terms of transparency, judicial review, and the efficiency of the EU's financial resources-thus offering better support to Member States. Such a step would have improved cooperation with the Commission and accountability to the European Parliament. $^{21}$

The Commission proposal was grounded on Article 352 TFEU. Under this norm, when an EU action should prove necessary within the framework of the policies of the Treaties to achieve one of the objectives indicated in the Treaties, but the Treaties have not provided the necessary powers, the Council, acting unanimously on a proposal from the Commission and after obtaining the consent of the European Parliament, shall adopt the appropriate measures. All these requirements are cumulatively satisfied in relation to the Commission's proposal. In terms of necessary powers, the ECJ in the Pringle case has clearly ruled that the Treaties do not confer any specific power on the European Union to establish a stability mechanism of the kind of the ESM. ${ }^{22}$ In terms of the objectives of the Treaties, the ECJ in the Pringle case also emphasized that maintaining the financial stability of the monetary union is one of the highest objectives of the EU, and that, under exceptional circumstances, providing financial assistance under strict conditionality is instrumental to pursuing this objective. ${ }^{23}$ In terms of necessary action, the action by the EU Council is essential to bring the management of the conditionality on which financial assistance is subordinated from an intergovernmental level to a proper EU domain. ${ }^{24}$ In this way, the

\footnotetext{
${ }^{16}$ See generally ECJ, Case C-370/12, Pringle v. Ireland, ECLI:EU:C:2012:756, Judgment of 27 Nov. 2012.

${ }^{17}$ See Pringle, Case C-370/12 at para. 65 (the machinery envisaged in Article 122(2) TFEU, whose operation is confined to the occurrence of exceptional circumstances, does not constitute a legal basis for such a mechanism).

${ }^{18}$ See ECJ, Case 22/70, Comm'n v. Council (ERTA), ECLI:EU:C:1971:32, Judgment of 31 Mar. 1971 at paras. 95-96.

${ }^{19}$ See ECJ, Case C-55/00, Gottardo v. INPS, ECLI:EU:C:2002:16, Judgment of 15 Jan. 2002 at para. 32.

${ }^{20}$ The reference to conditionality contained in Article 13(3) of the ESM Treaty is a sort of consistency clause, which ensures the compatability with the measures of economic coordination under the TFEU. In this respect, it is an expression of the principle of loyal cooperation and the primacy of EU Law. See Alberto de Gregorio Merino, Legal Developments in the Economic and Monetary Union During the Debt Crisis: The Mechanism of the Financial Assistance, 49 CommON MкT. L. ReV. 1613, 1635-37 (2012).

${ }^{21}$ See Regulation proposal, supra note 4, at 5.

${ }^{22}$ See Pringle, C-370/12 at para. 64 (in this context, it is worth mentioning that Article 136(3) TFEU empowers only Member States to establish a stability mechanism).

${ }^{23}$ See id. at paras. $135-36$ (in its line of reasoning, the ECJ introduced an additional objective not explicitly indicated in the framework of the Treaties). See also Vestert Borger, The ESM and the European Court's Predicament in Pringle, 14 GERMAN L. J. 113, 134-35 (2013).

${ }^{24}$ See Francesco Pennesi, The Accountability of the European Stability Mechanism and the European Stability Fund: Who Should Answer for Conditionality Measures, 3 EUR. PAPERS 511, 531 (2018).
} 
provision of financial assistance becomes justiciable before the ECJ and accountable to the European Parliament and national parliaments.

The proposal of the Commission is not altogether surprising. The ECB, in its opinion on the draft European Council decision amending Article 136 TFEU with regard to a stability mechanism for countries whose currency is the Euro, had emphasized the opportunity that at an appropriate moment the ESM would become an EU mechanism. ${ }^{25}$ The debate over the establishment of the ESM was also accompanied by proposals for the creation of a proper $\mathrm{EMF}^{26}$ or a European Mechanism for Sovereign Debt Crisis Resolution. ${ }^{27}$

From a substantive point of view, the proposal of the Commission contained significant innovations in comparison with the ESM Treaty. First, the EMF would contribute to safeguarding the financial stability of the Euro area and the financial stability of the participating Member States, whereas the present ESM Treaty speaks only of intervention indispensable to safeguard the financial stability of the Euro area as a whole and of its Member States. The deletion of the reference to the "whole" Euro area would allow an intervention in the absence of a systemic crisis endangering the whole Euro-zone, but in the presence of a crisis affecting a specific Euro country. ${ }^{28}$ Second, the EMF would be accountable to the European Parliament and Council for the execution of its tasks. In connection with this, the EMF would be required to submit to the Commission, the Council, and the European Parliament an annual report on its activity. Moreover, the European Parliament could ask questions of the EMF Managing Director who would be obliged to answer orally or in writing. As a corollary to the incorporation of the ESM in the EU legal order, the EMF acts must be consistent with the EU Treaties and the EU Charter of Fundamental Rights, and could be challenged before the ECJ. ${ }^{29}$ Third, the EMF would

\footnotetext{
${ }^{25}$ See Opinion of the European Central Bank, CON/2011/24, point 8 (Mar. 17, 2011).

${ }^{26}$ See generally Daniel Gros \& Thomas Mayer, How to Deal with Sovereign Default in Europe: Create the European Monetary Fund Now!, CEPS Policy Brief No. 202 (May 17, 2010), available at SSRN: https://ssrn.com/abstract=1610303 The proposal was to be adopted within a framework of enhanced cooperation between the Euro-zone countries. The participating countries would have provided financial contributions, based on a percentage of both excessive deficit and debt with respect to the Maastricht parameters, as these constitute a warning sign of imminent insolvency or a liquidity crisis. Those contributions would be invested in investment-grade government debt of Euro countries. In the case of necessity, any participating country could call on the funds, up to the concurrence of the amount deposited, provided that its adjustment program had received approval by the Eurogroup. Any further drawing of funds would be permitted solely in the presence of an adjustment program supervised by the Commission and the Eurogroup.

${ }^{27}$ See generally François Gianviti et al., A European Mechanism for Sovereign Debt Crisis Resolution: A Proposal, Bruegel Blueprint (Nov. 9, 2010), http://aei.pitt.edu/15123/1/101109_BP_Debt_resolution_BP_clean_01.pdf. The European Mechanism would have been based upon two cornerstones: First, a procedure- to be administered by the EU Court of Justice-for negotiation between a sovereign borrower burdened with unsustainable debt and its private creditors, with the view to achieving an agreed solution to make debt sustainable; second, a mechanism for providing insolvent countries with financial assistance to be granted against an agreement between debtors and creditors capable of re-establishing the borrower's solvency.

${ }^{28}$ See generally Michael Ioannidis, Towards a European Monetary Fund: Comments on the Commission's Proposal, EU LAW ANALYSIS (Jan. 31, 2018), http://eulawanalysis.blogspot.com/2018/01/towards-european-monetary-fund-comments.html (the focus would have shifted on the Member States).

${ }^{29}$ See Pennesi, supra note 24 , at 539-41 In this way, the divergent rulings delivered by the ECJ in Florescu, Mallis, and Ledra would be reconciled. In Florescu, the ECJ ruled that the Memoranda of Understanding signed by the Commission and the Romanian authorities in the framework of the assistance programme under Regulation 332/2002, supra note 5, was an act grounded on EU law the legality of which was challengeable before the ECJ (ECJ, Case C-258/14, Florescu et al. v. Sibiu et al., ECLI:EU:C:2017:448, Judgment of 13 June 2017). In Mallis, the ECJ ruled that, although the Eurogroup endorsed the conditionality related to the bail-in of the Cypriot banking system approved by the ESM Board of Governors, this endorsement could not constitute basis for annulment, because the Eurogroup was an informal body and not a EU institution, and its acts were not binding but merely possessed an informative nature (ECJ, Joined Cases C-105-109/15 P, Mallis et al. v. Comm'n \& ECB, ECLI:EU:C:2016:702, Judgment of 20 Sep. 2016). In Ledra, the ECJ restated that the concession of assistance to Cyprus by the ESM was an international act beyond the domain of EU law, but it contextually underscored that in this process the Commission has the task of ensuring the consistency of the ESM decision with EU law. This may imply an action for damages, even though the burden of proof is very high (ECJ, Joined Cases C-8-10/15, Ledra Advert. Ltd. et al. v. Comm'n \& ECB, ECLI: EU:C:2016:701, judgment of 20 Sep. 2016).
} 
operate in favor of the banking system in two ways: A direct recapitalization of credit institutions and credit lines or guarantees in favor of the Single Resolution Board (SRB). ${ }^{30}$ The assistance to credit institutions would take place when an EMF Member State had been affected by severe difficulties with its banking sector, which could not be cured without significantly endangering its fiscal sustainability, because there would be a risk of contagion from banks to states or alternative routes would have the effect of endangering market access. ${ }^{31}$ The assistance to the SRB would be provided jointly with the participating states-namely, those non-Euro countries that have decided to establish a close cooperation with the ECB in the field of prudential supervision of financial institutions. The financial terms and conditions of this assistance would be incorporated in a financial assistance agreement to be concluded by the EMF and the participating states with the SRB. ${ }^{32}$

\section{The Transformation of the ESM}

Article 2 of the proposal of Council Regulation provided scant indications relating to the transformation of the ESM. This norm stipulated that the EMF shall succeed to and replace the ESM in its legal positions and assume all its rights and obligations. This process should have been completed upon the entry into force of the Regulation or the consent of the ESM. This vagueness was because the ESM Treaty does not contain any rule dealing with this phenomenon. Thereby, the whole process was in the hands of the ESM Member States. It was their competence, as Herren der Veträge (Masters of the Treaty), to extinguish the ESM and to transfer its functions to the EMF on the basis of the general rules governing the succession between international organizations.

Broadly speaking, the phenomenon of succession between international organizations presents significant differences in comparison with that of state succession. This is because an international organization does not possess the whole rights and duties of a State, but only those rights and duties related to the purposes and functions arising under the establishing treaty and the relevant practice. ${ }^{33}$ Because the rights and obligations of an international organization are connected with its functions, the succession between international organizations consists of the transfer of functions from one organization to another. ${ }^{34}$ In the context of the EMF succession to the ESM, three profiles come into play: The forms of transformation, the methods of transformation, and the results of transformation.

\footnotetext{
${ }^{30}$ See generally Council Regulation 1024/2013 of Oct. 15, 2013, Conferring Specific Tasks on the European Central Bank Concerning Policies Relating to the Prudential Supervision of Credit Institutions, 2013 O.J. (L 287) 63 (EC). The SRB is an EU agency entrusted with the task of ensuring the effective and consistent functioning of the Single Resolution Mechanism (SRM). See also Danny Busch, Governance of the Single Resolution Mechanism, in EUROPEAN BANKING UnION 281 (Danny Busch \& Guido Ferrarini eds., 2015).

${ }^{31}$ The credit institutions which would benefit from this recapitalization must be of systemic relevance or must pose a serious threat to the financial stability of the Euro area or the requesting state. In any case, the requesting state must contribute to the recapitalization. This possibility has been already envisaged in ESM Board of Governors Resolution of 8 December 2014 concerning the establishment of the instrument of the direct recapitalization of institutions (DRI) and lately incorporated in the EMF Treaty. See generally European Stability Mechanism Board of Governors Resolution (Dec. 8, 2014), https://www.esm.europa.eu/ sites/default/files/20141208_establishment_of_the_instrument_for_the_direct_recapitalisation_of_institutions.pdf.

${ }^{32} \mathrm{See}$ Christos V. Gortsos, The Proposed Legal Framework for Establishing a European Monetary Fund (EMF): A Systematic Presentation and a Preliminary Assessment 28-31 (2017). At 10.2139/ssrn.3090343.

${ }^{33}$ See Reparation for Injuries Suffered in the Service of the United Nations, Advisory Opinion, 1949 I.C.J. 174, 180 (April 11). See also Michel Virally, La Notion de Fonction dans la Théorie de l'Organisation Internationale, in MÉLANGES OFFERTS A CHARLES ROUSSEAU 277 (1974) (on functionalism).

${ }^{34}$ See Patrick R. Myers, The Succession between International Organizations 11-12 (1993).
} 


\section{The Forms of Transformation}

The issue of the succession between international organizations became topical following the Second World War when the United Nations and a number of other international organizations-such as the Food and Agricultural Organization, the United Nations Educational, Scientific and Cultural Organization, the World Health Organization, and the World Meteorological Organization-were established and operated in the same fields as pre-existing international organizations. ${ }^{35}$ From this practice it is possible to establish five forms of succession: (1) Replacement, when an organization is replaced by a new one with basically the same functions; (2) absorption, when a functionally limited organization is absorbed by a broader organization and becomes one of its organs; (3) merger, when two or more organization are combined to form a new one; (4) separation, when a subsidiary organ of an existing organization is separated from its parent institution to form a new organization; and (5) transfer of specific functions, when some functions of an organization are transferred to another. ${ }^{36}$

Against this background, the transformation of the ESM into the EMF can be subsumed under the category of absorption. In effect, the ESM was to be dissolved and its functions and responsibilities were to be reconstituted in the EMF, which was designed as an organ of the EU. ${ }^{37}$ The practice of international organizations records at least two instances of absorption. In 1969, the International Bureau of Education (IBE) was absorbed into the United Nations Educational, Scientific and Cultural Organization (UNESCO). The IBE was established in 1926 as a private organization and subsequently was transformed in an intergovernmental organization operating as an information center for matters concerned with education. Because of financial difficulties, in 1969 it was dissolved and became a subsidiary organ of the UNESCO. ${ }^{38}$ In 1978, the International Patent Institute (IPI) was absorbed into the European Patent Organization (EPO). The IPI was established in 1947 as an intergovernmental organization with the purpose of centralizing patent searching and archiving. In the 1973 EPO establishing agreement it was stipulated that assets and liabilities of the IPI were to be transferred to the EPO with the former becoming a branch of the latter. ${ }^{39}$

Of the two instances mentioned above, the closest to the absorption of the ESM into the EU is the absorption of the IBE into the UNESCO, as in both cases the absorbed organization has become-or was to become-a specific organ of the absorbing organization. Under the Agreement between the UNESCO and the IBE, the IBE transferred to the UNESCO all the functions it had performed under the 1929 Statutes, ${ }^{40}$ and it was reconstituted as an autonomous body with the same name within the framework of the UNESCO. ${ }^{41}$ In this context two aspects are worth consideration.

From an institutional point of view, the IBE governing body-the Council-is composed of Member States designated by the UNESCO General Conference. Moreover, the Council of the IBE submits a draft general program and budget to the General Conference of the UNESCO under which it defines its range of activities (Article V(a), 1968 Statutes). ${ }^{42}$ From a substantive point of

\footnotetext{
${ }^{35}$ See Hungdah Chiu, Succession in International Organisations, 54 INT'L CoMP. L. Q. 83, 89-90 (1954) (respectively, the League of Nations, the International Institute of Agriculture, the International Institute of Intellectual Cooperation, the International Office of Public Hygiene, and the International Meteorological Organisation).

${ }^{36}$ See MYers, supra note 34, at 15.

${ }^{37} \mathrm{Cf}$. infra Part III on this point.

${ }^{38}$ See MYers, supra note 34, at 27.

${ }^{39}$ See MYers, supra note 34, at 27-28.

${ }^{40}$ See generally Statutes of the International Bureau of Education, July 25, 1929, T.I.A.S. 5325, 14 U.S.T. 311.

${ }^{41}$ See Agreement Between the United Nations Educational, Scientific and Cultural Organization, and the International Bureau of Education, signed on 25 and 29 November and Entered into force $1^{\text {st }}$ January 1969, in COLLECTION OF BASIC TEXTs (IBE) 3 (2016) [hereinafter Agreement]. See also Douglas Hodgson, International Bureau of Education MEPIL (2006) (under Article 3, the IBE enjoys a large and functional autonomy).

${ }^{42}$ See 1968 Statutes, in UNESCO, Records of the General Conference Fifteenth Session: Resolutions, at 109 (Paris, 1968).
} 
view, the IBE mandate under the 1968 Statute was enlarged in comparison with that under the 1929 Statutes. Under the 1929 Statutes, the IBE performed two main functions: To collect information relating to public and private education, and to participatein scientific research in this field by undertaking experimental and statistical research and making the results known to educators (Article 2, 1929 Statute). ${ }^{43}$ Under the 1968 Statute, the IBE received the tasks of: Preparing for-and organizing at least every two years-the sessions of the International Conference on Public Education; undertaking educational studies particularly on comparative education and publishing the results; coordinating its work with that of other institutions pursuing similar objectives; and maintaining and developing an international educational library and a permanent international exhibition of public education (Article II, 1968 Statutes). ${ }^{44}$

A similar outcome can also be seen in the ESM-EMF relationship. From an institutional point of view, the EMF Managing Director would no longer be appointed by the Board of Governors-like in the ESM-but by the EU Council, after consultation with the European Parliament, on the basis of a list of suitable candidates prepared by the Board of Governors (Article. 7, EMF Statute). Moreover, under the proposal for an EU Regulation, most of the decisions taken by the Board of Governors could enter into force only following an approval by the EU Council (Article 3(1), Regulation proposal). The EMF was also requested to prepare an annual report on its activities to be submitted to the European Parliament, the EU Council, and the Commission (Article 4, Regulation proposal), and contextually forwarded to the national parliaments of the EMF Member States (Article 5, Regulation proposal). From a substantive point of view, the most significant improvement in comparison with the ESM consists of the possibility of providing financial support in the form of lines or ceilings, or both, for guarantees on the liabilities of the SRB (Article 22, EMF Statute). ${ }^{45}$

\section{The Methods of Transformation}

The rules for the dissolution of an international organization are usually found in the statute of the organization or in a subsequent act. Generally speaking, it is quite rare for statutes of international organizations to contain the rules for their dissolution. This is because the aim of the founding states is not to confine the mandate of the organization to a specific time period. An exception is constituted by the statutes of the international financial institutions, because in this case, there are significant issues relating to the liquidation of assets and liabilities. In this context, the decision to terminate the operation is taken by a decision of the plenary organs in which all the Member States are represented and requires a certain voting quorum. ${ }^{46}$ Under the International Monetary Fund (IMF) establishing agreement, the Board of Governors may liquidate the IMF by simple majority (Article XXVII(2)). Under the International Bank for Reconstruction and Development (IBRD) and International Development Association (IDA) establishing agreements, the vote of a majority of the Governors, exercising a majority of the total voting power (Article VI(5)(b) IBRD, Article VII(5)(a) IDA), is required. Under the statutes of the regional development banks, the Board of Governors may terminate the operations of the relevant institution by a vote of two-thirds of the total number of Governors, representing not less than three-fourths of the total voting power of the members (Article 10(2) Inter-American Development Bank (IADB), Article 45 Asian Development

\footnotetext{
${ }^{43}$ See Agreement, supra note 41.

${ }^{44}$ See 1968 Statutes, supra note 42.

${ }^{45}$ In this context, the Board of Governors should have adopted the financial terms and conditions of the EMF support. The Managing Director should have signed the agreement on the basis of approval by the Board of Directors and would have had the authority to decide on the drawdown of the credit lines or the provision of guarantees on liabilities of the SRB. The Board of Directors should have adopted the detailed guidelines on the modalities for implementing EMF credit lines or guarantees to the SRB (Art. 22, EMF Statute).

${ }^{46}$ See Henry G. Schermers \& Niels M. Blokker, International Institutional Law 1049 (5th rev. ed. 2011).
} 
Bank (ASDB), Article 41 European Bank for Reconstruction and Development (EBRD). The exception is the African Development Bank (AFDB) statute, which requires a decision by the Board of Governors taken with three-fourths of the total voting power (Article 47).

Failing specific rules on dissolution in the establishing agreement, two routes are available: Either amending the charter to incorporate specific rules on dissolution and transfer of functions, or making an international agreement providing for the dissolution and transfer of functions. In the latter case, two possibilities arise. First, the Member States may stipulate an ad hoc international agreement containing rules for dissolution of the organization and transfer of functions. ${ }^{47}$ Second, the Member States may incorporate the norms on dissolution and liquidation in the treaty establishing the new international organization that is meant to take over the functions, assets, and liabilities of the old one. ${ }^{48}$ This second possibility seems more suitable because the rules on dissolution will enter into force at the same time as the establishment of the new organization. ${ }^{49}$

Practice also records a particular instance of succession between international organizations, for example, implied succession. It takes places when there are no specific measures providing for the dissolution and transfer of functions, assets, and liabilities from one organization to another organization. The Member States simply consider that the succeeding organization has taken over the functions of the pre-existing organization. Technically speaking, this is a form of tacit abrogation of the previous treaty that generally occurs when the whole matter is governed by the provisions of the new treaty. ${ }^{50}$ Such peculiar type of succession, however, may work only in relation to small organizations with few Member States, functions, assets, and liabilities. ${ }^{51}$

Unlike the above mentioned international financial institutions (IMF, IBRD, IDA, IADB, AFDB, ASDB, EBRD), the ESM Treaty is silent about the procedures for dissolution and the possible transfer of functions, assets, and liabilities. By contrast, the proposal of Council Regulation clearly stipulated that the EMF should have succeeded and replaced the ESM in all its legal positions, rights, and obligations. It further specified that this process was to be completed upon the entry into force of the Regulation or upon the consent of the ESM (Article 2). ${ }^{52}$ This consent, according to the proposal of Council Regulation, should have been given by the ESM Board of Governors in its capacity of highest decision making organ composed of all the representatives of the ESM Member States (Whereas Number 21). ${ }^{53}$ Nevertheless, the proposal of Council Regulation did not consider that under the ESM Treaty, the Board of Governors is not vested with the power to dissolve the organization and transfer its functions. To fill this lacuna, three

\footnotetext{
${ }^{47}$ See Hugo J. Hahn, Continuity in the Law of International Organizations, 11 DuKE L. J. 379, 390-91 (1962) (this is the case of the Protocol of July 22, 1946 dissolving the International Office of Public Hygiene (1907) into the WHO).

${ }^{48}$ See MYeRs, supra note 34, at 40-41 (In 1960, the agreement establishing the Caribbean Organization stipulated that at the entry into force functions of the Caribbean Commission would terminate, and assets and liabilities would pass on the Caribbean Commission. In 1967, the agreement establishing the East African Cooperation stipulated that the functions of the East African Common Services Organization would pass on the East African Community. In 1975, the agreement establishing the European Space Service stipulated that the conventions on the European Space Research Organization and the European Organization for Development of Space Vehicle Launchers were terminated, and the relevant rights were taken over by the new organization).

${ }^{49}$ See SCHERMERS \& BlOKKer, supra note 46 , at 1051.

${ }^{50}$ See Electricity Company of Sofia and Bulgaria (Belg. v. Bulg.), Preliminary Objection, 1939 P.C.I.J. Series A/B No 77, 92 (Apr. 4) (separate opinion by Anzilotti, J.) (this principle is now acknowledged in Article 59 of the 1969 Vienna Convention on the Law of Treaties, under which a treaty is considered terminated if all the parties to it make a later treaty relating to the same subject matter, and it appears from the later treaty-or is otherwise established—that the parties intended that the matter should be governed by that treaty, or the provisions of the later treaty are so far incompatible with those of the earlier one that the two treaties are not capable of being applied at the same time).

${ }^{51}$ See MYERS, supra note 34, at 42.

${ }^{52}$ As a product of that, all states that are party to the ESM Treaty should be members of the EMF at the entry into force of the Regulation (Whereas Number 22 Regulation proposal).

${ }^{53}$ See ESM Treaty art. 5(1) (the ESM Board of Governors is composed of the ministers of finance of all the ESM Member States. The prior consent of the Board of Governors reflects the fact that the ESM is an international financial institution based on an international agreement between the Euro countries).
} 
routes can be envisaged. First, the ESM Member States may decide to dissolve the ESM in a separate treaty. In this case, the ESM Board of Governors would acknowledge and implement such a decision in the ESM legal order. Second, the ESM Member States may amend the ESM establishing Treaty and empower the Board of Governors to dissolve the ESM and transfer functions and rights to the EMF. Third, the ESM Member States may provide their delegates in the ESM Board of Governors with the specific power to dissolve the organization and transfer functions and rights to the EMF. In this case, the Governors would not act as members of the ESM Board, but as representatives of Member States endowed with treaty making power- "full powers."

In order to overcome all these problems, the solution could be to take the opportunity presented by the ESM amending process to insert into the ESM Treaty a specific norm providing for dissolution and transfer of functions. Because the ESM is composed of a small number of Member States, and considering the exceptionality of the ESM stability support, the dissolution would require the unanimity of the ESM Board of Governors. This norm might be completed by a provision specifically concerning the transfer of functions to a future EMF. This may be perceived as a sign that the project of establishing an EMF is not completely abandoned.

\section{The Results of Transformation}

The outcome of this process of transformation is the extinction of the ESM as an intergovernmental organization in its own right and its reconstitution as a legal person of the EU. In this context, the proposal of Council Regulation clarified that the EMF would have been an EU body with legal personality (Whereas Number 17). The proposed Statute further specified that the EMF would have enjoyed in all the Member States the most extensive legal capacity accorded to legal persons under their laws. It could, in particular, acquire and dispose of movable and immovable property, and it may be a party to legal proceedings (Article 1). The conferment of the EU legal personality upon the EMF, though, leaves unanswered what status it exactly would have had in the EU legal order.

The fact that Article 352 TFEU was set as the legal basis for the proposed EMF Regulation may suggest that the EMF would have had a status akin to that of the European agencies. ${ }^{54}$ Nevertheless, European agencies perform informational and coordinating functions and, in some cases, enjoy regulatory or quasi-regulatory powers, ${ }^{55}$ like the European Banking Authority (EBA).$^{56}$ This is an altogether different task from that of the EMF, which is mandated to mobilize funding and to provide stability support in favor of the Euro countries, or their financial institutions, in order to preserve the financial stability of the Euro area.

Against this background, a more reasonable solution might be to concoct a body akin to the European Investment Bank (EIB). The EIB is an autonomous body within the EU legal framework endowed with legal personality (Article $308 \mathrm{TFEU}) .{ }^{57}$ Its task consists of making loans and

\footnotetext{
${ }^{54}$ See Paul Craig, European Administrative Law 148-50 (2006) (in fact, nine European agencies are based upon former Article 235 or Article 308, which correspond to current Article 352 TFEU). See also Sarantis-MIchail Niotis, The Birth of the EMF 27 (MCEL, Master Working Paper 2018/12) (the structure of the EMF would reflect the fundamental elements of an agency).

${ }^{55}$ See Paul Craig \& Gràinne de Burca, EU law: Text, Cases and Materials 69-70 (6th ed. 2011).

${ }^{56}$ See Regulation 1093/2010 of the European Parliament and the Council of 24 November 2010 Establishing a European Supervisory Authority (European Banking Authority), Amending Decision 716/2009/EC, and Repealing Commission Decision 2009/78/EC, 2010 O.J. (L 331) 12 (EC) (the EBA is a EU regulatory agency that was established in 2011 with the mandate to conduct stress tests on European banks, increase transparency in the European financial system, and identify weaknesses in banks' capital structures).

${ }^{57}$ See ECJ, Case C-85/86, Comm'n v. EIB, ECLI:EU:C:1988:110, Judgment of 3 Mar. 1988 at para. 29 (however, its operational and institutional autonomy does not imply that the EIB is separated from the EU and independent from EU rules). This point was subsequently restated in ECJ, Case C-11/00, Comm'n v. ECB, ECLI:EU:C:2003:395, Judgment of 10 July 2003 at para. 135, with specific reference to the ECB (the ECB independence "does not have the consequence of separating it entirely from the European Community and exempting it from every rule of Community law").
} 
guarantees aimed at contributing to the balanced and steady development of the internal market in the interests of the European Union (Article 309 TFEU).$^{58}$ Membership is reserved to EU Member States, and voting power is correlated with quota of capital statutorily subscribed. In this context, it is worth emphasizing that the structure of the EMF closely resembles that of the EIB. In both cases, there is a Board of Governors composed of Member States' ministers (Article 7 EIB Statute, Article 5 EMF Statute) and a Board of Directors appointed by the Board of Governors (Article 9 EIB Statute, Article 6 EMF Statute). ${ }^{59}$ In the EIB, there is a Management Committee (Article 11 EIB Statute), and in the EMF, there is a Managing Director (Article 7 EMF Statute) ${ }^{60}$ Moreover, the operational task of the EMF substantively mirrors that of the EIB. In both cases, there is a provision of financial resources: The EIB finances its Member States and their private or public undertakings, and the EMF finances Member States and their credit institutions. Further, the mandate of the EMF is complementary to that of the EIB. The EIB undertakes the task of ensuring the harmonious development of the internal market (Article 309 TFEU), while the EMF pursues the goal of safeguarding the financial stability of the Euro area and its Member States (Article 3 EMF Statute). Moreover, both the EIB and the EMF operate as a sort of lender of last resort: The EIB concedes financing as far as resources are not available elsewhere on reasonable terms (Article 16, EIB Statute), while the EMF arranges financial assistance in favor of its Member States which are experiencing, or are threatened by, severe financing problems (Article 3 EMF Statute). Finally, both the EIB and the EMF are enabled to cooperate with international institutions operating in their fields of activity (Article 14 EIB Statute, Article 41 EMF Statute).

Such a solution, however, would require a different legal basis: Not so much Article 352 TFEU, ${ }^{61}$ but rather a treaty-amending procedure. Under the simplified revision machinery envisaged at paragraph 6 of Article 48 TEU, the Commission is enabled to make a proposal of revision of part III of the TFEU relating to EU policies and actions. The European Council might acknowledge this proposal and, acting unanimously, may adopt a decision amending the relevant part of the TFEU that shall enter into force only following the fulfilment of Member States' respective constitutional requirements. ${ }^{62}$ In this respect, it is worth considering that in the Pringle case, the ECJ ruled that the provision of financial assistance by the ESM falls in the purview of economic policy - namely, in the third part of the TFEU ${ }^{63}$ — and does not confer any new competence upon the EU. ${ }^{64}$ Thereby, the procedure envisaged by Article 48(6) could be perfectly resorted to in this case. In this context, a new provision could be added to Article 136 TFEU stipulating the establishment of the EMF and clarifying whether Article 136(3), which has allowed Euro countries to create the ESM, is superseded.

\section{E. Conclusion}

The proposal for the establishment of an EMF submitted by the European Commission in December 2017 deserved a better outcome. It was driven by the sensible purpose of making

\footnotetext{
${ }^{58}$ See generally D.R.R. Dunnett, The European Bank for Reconstruction and Development: A Legal Survey, 28 COMMON MKT. L. ReV. 571 (1991) and Giovannagelo Marchegiani, La Banque Européenne d'investissement, in COMMENTAIRE J. MEGRET 429-558 (2d ed. 2000).

${ }^{59}$ In terms of Board of Directors, a significant difference between the EIB and the EMF is that in the first case, the Commission appoints a voting member, while in the other, the Commission appoints a non-voting member. Another difference is that the EIB Directors are responsible only to the EIB.

${ }^{60}$ This quantitative difference in the composition of the managing organ is because the EIB operates on continuous basis, while the EMF operates under exceptional circumstances.

${ }^{61}$ Cf. supra Part C.

${ }^{62}$ Cf. Council Decision 2011/199, supra note 10.

${ }^{63}$ See Pringle, Case C-370/12 at paras. 63, 70.

${ }^{64} \mathrm{See} i d$. at paras. 73,75 .
} 
the acts of the ESM: On the one hand, accountable to the Commission, Council, and European Parliament, and on the other hand challengeable before the ECJ. Further, the design of bringing the stability mechanism under the umbrella of the European Union would have marked a change of pace in the intergovernmental approach that so far has characterized the management of the financial crisis of the Euro countries. All this has not occurred, and the substantive innovations contained in the Commission's proposal are to be incorporated in the ESM Treaty by virtue of an amending process. This implies that the intergovernmental nature of the stability support is preserved.

Nevertheless, the idea of an EMF has not perished; it is like an underground stream and can surface again. In this vein, it is necessary to highlight two flaws that have emerged in the analysis of the proposed transformation of the ESM. The first flaw concerns the lack of any rule on succession in the ESM Treaty. This lacuna may be cured by inserting into the ESM Treaty amending process a specific norm providing for the dissolution and liquidation of the ESM and, possibly, the transfer of functions to the EMF when it comes into being. In this way, the ESM amended Treaty may contain an implied pledge to establish the EMF. The second flaw concerns the unclear status that the EMF would enjoy in the EU legal framework. The choice of basing the proposal of Council Regulation on Article 352 TFEU could indicate that the EMF should have a status akin to that of a European agency. Nevertheless, European agencies merely exert coordinating or regulatory functions while the EMF would provide financial assistance. A more reasonable solution would be to place the EMF on the same footing as the EIB, even though this option would imply amending the TFEU.

Cite this article: Megliani M (2020). From the European Stability Mechanism to the European Monetary Fund: There and Back Again. German Law Journal 21, 674-685. https://doi.org/10.1017/glj.2020.42 